\title{
IMMUNOHAEMATOLOGICAL AND BIOCHEMICAL CHARACTERISTICS IN RH-D HAEMOLYTIC DISEASE OF NEWBORN
}

Sajith Vilambili, Meena Dharmadas², Kumari Krishnakumariamma Chakrapani Usha ${ }^{3}$, Shaiji Panthiyil Shahulhameed ${ }^{4}$, Chitra James ${ }^{5}$, Anjaly Padmavilas Sasikala6, Soonam John7, Vineeth Rajagopal ${ }^{8}$

${ }^{1}$ Assistant Professor, Department of Transfusion Medicine, Government Medical College, Thrissur, Kerala.

${ }^{2}$ Professor and HOD, Department of Transfusion Medicine, Government Medical College, Trivandrum, Kerala.

3 Professor and HOD, Department of Transfusion Medicine, Sree Mookambika Institute of Medical Sciences, Kulasekharam, Tamilnadu.

${ }^{4}$ Assistant Professor, Department of Transfusion Medicine, Government Medical College, Trivandrum, Kerala.

${ }^{5}$ Assistant Professor, Department of Transfusion Medicine, Government Medical College, Kollam, Kerala.

${ }^{6}$ Senior Resident, Department of Transfusion Medicine, Government Medical College, Thrissur, Kerala.

${ }^{7}$ Assistant Professor, Department of Transfusion Medicine, Government Medical College, Trivandrum, Kerala.

${ }^{8}$ Assistant Professor, Department of Family Medicine, Government Medical College, Calicut, Kerala.

\section{ABSTRACT}

\section{BACKGROUND}

Rh-D haemolytic disease of foetus and newborn (HDFN) is an ailment in which lifespan of infant's erythrocytes were shortened by the action of placentally transferred maternal anti-D specific for inherited paternal red cell antigens.

The aim of this study is to describe the immunological profile of Rh-D HDFN.

Settings and Design- This was a descriptive study conducted among newborn with Rh-D HDFN. Setting was Depts. of Transfusion Medicine and Paediatrics in Govt. Medical College, Trivandrum.

\section{MATERIALS AND METHODS}

Enrolment of newborn was done according to the inclusion criteria. Demographic details, maternal history, bilirubin and haemoglobin levels were noted. Blood group and peak antibody level of mother were recorded. Direct antiglobulin test, blood grouping and elution was performed in infant.

Statistical Analysis- All statistical data were analysed using SPSS software version 16.

\section{RESULTS}

In mothers of infants with Rh-D HDFN, $3(6.8 \%)$ had a titre of 2, $6(13.6 \%)$ had a titre of $4,3(6.8 \%)$ had a titre of $8,2(4.6 \%)$ had a titre of $16,3(6.8 \%)$ had a titre of $32,7(15.9 \%)$ had a titre of $64,6(13.6 \%)$ had a titre of $128,7(15.9 \%)$ had a titre of 256,5 $(11.4 \%)$ had a titre of 512 and $2(4.6 \%)$ had titres of 1024 . While considering DAT positivity in infants with Rh-D HDFN, 1 (2.3\%) fell in grade 1, $33(75 \%)$ in grade 2, $6(13.6 \%)$ in grade 3 and $4(9.1 \%)$ in grade 4 categories.

\section{CONCLUSION}

High titres of anti-D ranging from 128 - 1024 were observed in 45.5\% of mothers of infants with Rh-D HDFN. While considering DAT positivity in infants with Rh-D HDFN, majority fell in grade 1 and 2 categories.

\section{KEYWORDS}

Haemolytic Disease of Foetus and Newborn, Hyperbilirubinaemia, Antibody, Rh-D, Direct Antiglobulin Test, Elution.

HOW TO CITE THIS ARTICLE: Vilambil S, Dharmadas M, Usha KKC, et al. Immunohaematological and biochemical characteristics in RH-D haemolytic disease of newborn. J. Evolution Med. Dent. Sci. 2017;6(78):5547-5552, DOI: 10.14260/jemds/2017/1205

\section{BACKGROUND}

Rh-D haemolytic disease of foetus and newborn (HDFN) is an ailment in which lifespan of infant's erythrocytes were shortened by the action of placentally transferred maternal anti-D specific for inherited paternal red cell antigens. ${ }^{1}$

Programs for ABO grouping, Rh typing, antenatal antibody screening and other advanced therapeutic modalities which focused on foetuses and neonates at risk had reduced the burden of disease in developed nations. ${ }^{2}$

'Financial or Other Competing Interest': None.

Submission 08-07-2017, Peer Review 18-09-2017,

Acceptance 23-09-2017, Published 28-09-2017.

Corresponding Author:

Dr. Sajith Vilambil,

Assistant Professor

Department of Transfusion Medicine,

Government Medical College,

Thrissur-680596, Kerala.

E-mail: drsajithmenon@gmail.com

DOI: $10.14260 /$ jemds $/ 2017 / 1205$

(c) $($ ) $($ )
Implementation of same had posed both organisational and economic challenges in countries with a low human development index. ${ }^{3}$

Even though there were 160 blood banks in Kerala, routine antenatal antibody screening was performed only in a very few centres. Hence, assessing the immunological profile of Rh-D HDFN was undertaken in this study.

\section{MATERIALS AND METHODS}

This was a descriptive study done in 44 neonates who had Rh-D HDFN. Study setting was Dept. of Transfusion Medicine and Neonatology division of Sree Avittom Thirunal Hospital for women and children in Govt. Medical College, Trivandrum.

As a policy of institution, newborn with increased bilirubin levels and those born to mothers with antenatal antibody screen positivity were kept under observation. Those neonates fulfilling the inclusion criteria were enrolled in this research. Study was finished in 18 months, the timeframe from 01-03-2012 to 30-08-2013. 


\section{Inclusion Criteria for Rh-D HDFN}

1. Maternal antibody screening was positive for anti-D and presence of $\mathrm{D}$ antigen in newborn.

2. No ABO incompatibility between mother and neonate.

3. Positive DAT and elution in neonate.

4. Hyperbilirubinaemia within first 24 hours of birth.

5. No other diagnosed cause for increased bilirubin.

\section{Exclusion Criteria}

Features of HDFN concomitantly with any condition attributed to hyperbilirubinaemia.

Details such as name, age, IP no., bed no. and addresses were recorded. Maternal details such as parity and blood group were noted. Hyperbilirubinaemia was classified according to chart provided by American Academy of Paediatricians (AAP). The disease was graded as mild, moderate, severe and very severe as described by Andrew et $\mathrm{al}^{4}$ (Mild- Grade 0; $\mathrm{Hb}>12.5 \mathrm{~g} / \mathrm{dL}$, no transfusions, ModerateGrade $1: \mathrm{Hb}>12.5 \mathrm{~g} / \mathrm{dL}+$ top-up or exchange transfusion, Severe- Grade $2: \mathrm{Hb}<12.5 \mathrm{~g} / \mathrm{dL}+$ exchange transfusion, Very severe- Grade 3: Intra-uterine transfusions and/or $\mathrm{Hb}<10.0$ $\mathrm{g} / \mathrm{dL} \pm$ exchange transfusions or foetal death). Anaemia was graded according to description in Wintrobe's Haematology 5 (No- Hb $\geq 17$ g\%, Mild- Hb 14 - 17 g\%, Moderate- Hb 12 - 14 $\mathrm{g} \%$, Severe- $\mathrm{Hb}<12 \mathrm{~g} \%$ ).

Treatment was graded as described in Wintrobe's Haematology 6 (Grade 0- no treatment, Grade 1- phototherapy alone, Grade 2- phototherapy and IVIG, Grade 3phototherapy, IVIG and single exchange transfusion, Grade 4phototherapy, IVIG and multiple exchange transfusions) haemoglobin levels, disease severity and intensity of treatment were recorded.

$10 \mathrm{~mL}$ venous blood was collected from mothers. Blood group and presence of antibody was confirmed in the drawn sample. Peak antibody titre value performed during antenatal period was noted down. Immuno-haematological investigations was done in $5 \mathrm{~mL}$ of umbilical cord blood collected during delivery was used for performing.

$\mathrm{ABO}$ grouping was done by test tube method. Forward grouping was done using monoclonal anti-A, anti-B and antiAB by tulip diagnostics.

If necessary, serum grouping was performed using pooled $\mathrm{A}_{1}, \quad \mathrm{~B}$ and $\mathrm{O}$ group cells. After centrifugation, either haemolysis or agglutination in tests with red cells and serum constituted positive test results. Red cell test results were compared with those obtained in serum tests.

Determination of Rh-D type of red cells was done with monoclonal IgM anti-D by tube test.

After centrifugation, agglutination in the test sample combined with agglutination in positive control and a smooth suspension in negative control tube indicated that the red cells under investigation were D-positive.

A smooth suspension of red cells in the test sample and negative control tube with positivity in positive control is a negative test result. Those samples were tested further for the presence of weak D-antigen by an indirect antiglobulin procedure.

Monoclonal IgG anti-D and polyspecific antihuman globulin reagents were used for weak-D tests. Agglutination in the anti-D tube and none in the control tube constituted a positive test result.
Absence of agglutination in the anti-D tube and control tube in D negative samples were confirmed by addition of IgG coated red cells.

Gel cards with antihuman globulin reagent were used for indirect antiglobulin tests. IAT was done by adding $50 \mu \mathrm{L}$ of red cells suspended in LISS solution and $25 \mu \mathrm{L}$ of serum to microtubes. It was incubated for $15 \mathrm{mts}$ at $37^{\circ} \mathrm{C}$ and centrifuged for $10 \mathrm{mts}$. Agglutinated cells which formed a red line on the surface of the gel or agglutinates dispersed in the gel indicated a positive result. Compact button of cells on the bottom of the microtube indicated a negative test.

A positive reaction in antibody screening test with 3 cell panel indicated the presence of irregular antibodies. Identification tests were done on those samples using 11 cell panel.

Direct antiglobulin test was done using LISS Coombs gel card; $50 \mu \mathrm{L}$ of the red cell suspension was added to the appropriate microtube and it was centrifuged for 10 minutes.

Results were read and graded. (4+ - solid band of red cells on the top of the gel column, $3+$-agglutinated red cells in the upper half of the gel column, 2+-red cell agglutinates through the length of the column, 1+ -red cell agglutinates mainly in the lower half of the gel column with some unagglutinated red cells pelleted at the bottom, Negative-a pellet at the bottom and no agglutinates in the matrix of the gel column). A positive result indicated that the red cells were sensitised with IgG antibodies and/or complement. Presence of antibody was confirmed by elution tests.

DAT positive red cells in Rh HDFN were eluted using glycine- $\mathrm{HCl} /$ EDTA eluting solution. If eluate was reactive and final wash supernate was non-reactive, then eluate reactions were valid. If eluate was non-reactive and final wash supernate was nonreactive, then no antibody was eluted.

\section{Ethics}

Study was approved by human ethical committee and review board of institution. Parents of all study subjects were counselled separately about the nature and effects of the study and a written consent was obtained from them.

\section{Statistical Analysis}

Statistical data analysis was done in SPSS software version 16. Expression of continuous variables was as mean \pm standard deviation. Expression of qualitative data was as frequencies and percentages. Correlation between variables was done using spearman correlation test. All 'p' values were two tailed. $\mathrm{P}$ value $<0.05$ were considered statistically significant.

\section{RESULTS}

In mothers of infants with Rh-D HDFN, 3 (6.8\%) had a titre of 2; $6(13.6 \%)$ had a titre of $4,3(6.8 \%)$ had a titre of 8,2 $(4.6 \%)$ had a titre of $16,3(6.8 \%)$ had a titre of $32,7(15.9 \%)$ had a titre of $64,6(13.6 \%)$ had a titre of $128,7(15.9 \%)$ had a titre of 256, $5(11.4 \%)$ had a titre of 512 and 2 (4.6\%) had titres of 1024 . While considering DAT positivity in infants with Rh-D HDFN, 1 (2.3\%) fell in grade 1, 33 (75\%) in grade 2; $6(13.6 \%)$ in grade 3 and $4(9.1 \%)$ in grade 4 categories. 


\begin{tabular}{|c|c|c|}
\hline Grades of DAT & Frequency & Percentage \\
\hline Negative & 0 & 0.0 \\
\hline 1 & 1 & 2.3 \\
\hline 2 & 33 & 75.0 \\
\hline 3 & 6 & 13.6 \\
\hline 4 & 4 & 9.1 \\
\hline Total & $\mathbf{4 4}$ & $\mathbf{1 0 0 . 0}$ \\
\hline \multicolumn{2}{|c|}{ Table 1. Grading of Results of DAT } \\
\hline
\end{tabular}

\begin{tabular}{|c|c|c|c|}
\hline Variable (n- 44) & $\begin{array}{c}\text { Correlation } \\
\text { Coefficient }\end{array}$ & P value & Interpretation \\
\hline $\begin{array}{c}\text { Risk of peak } \\
\text { bilirubin levels }\end{array}$ & .016 & .919 & $\begin{array}{c}\text { No significant } \\
\text { correlation }\end{array}$ \\
\hline $\begin{array}{c}\text { Cord blood } \\
\text { haemoglobin }\end{array}$ & .012 & .937 & $\begin{array}{c}\text { No significant } \\
\text { correlation }\end{array}$ \\
\hline $\begin{array}{c}\text { Severity of } \\
\text { disease }\end{array}$ & .015 & .924 & $\begin{array}{c}\text { No significant } \\
\text { correlation }\end{array}$ \\
\hline $\begin{array}{c}\text { Intensity of } \\
\text { treatment }\end{array}$ & .021 & .891 & $\begin{array}{c}\text { No significant } \\
\text { correlation }\end{array}$ \\
\hline \multicolumn{4}{|r|}{ Table 2. Correlation of Grades of DAT } \\
in Infants with Rh-D HDFN
\end{tabular}

In Rh-D HDFN grades of DAT were not significantly correlated with risk of peak bilirubin levels, cord blood haemoglobin, disease severity and intensity of treatment. Correlation was significant at the 0.01 level.

\begin{tabular}{|c|c|c|c|}
\hline Variable (n- 44) & $\begin{array}{c}\text { Correlation } \\
\text { Coefficient }\end{array}$ & P value & Interpretation \\
\hline Grades of DAT & .028 & .855 & $\begin{array}{c}\text { No significant } \\
\text { correlation }\end{array}$ \\
\hline $\begin{array}{c}\text { Risk of peak } \\
\text { bilirubin levels }\end{array}$ & .911 & .001 & $\begin{array}{c}\text { Significant } \\
\text { positive } \\
\text { correlation }\end{array}$ \\
\hline $\begin{array}{c}\text { Cord blood } \\
\text { haemoglobin }\end{array}$ & -.844 & .001 & $\begin{array}{c}\text { Significant } \\
\text { negative } \\
\text { correlation }\end{array}$ \\
\hline $\begin{array}{c}\text { Severity of } \\
\text { disease }\end{array}$ & .732 & .001 & $\begin{array}{c}\text { Significant } \\
\text { positive } \\
\text { correlation }\end{array}$ \\
\hline $\begin{array}{c}\text { Intensity of } \\
\text { treatment }\end{array}$ & .912 & $\begin{array}{c}\text { Significant } \\
\text { positive } \\
\text { correlation }\end{array}$ \\
\hline \multicolumn{3}{|c|}{ Table 3. Antibody Titres in Mothers } \\
of Infants with Rh-D HDFN
\end{tabular}

Antibody titres in mothers of infants with Rh-D HDFN were positively correlated with risk of peak bilirubin levels, severity of disease and intensity of treatment.

Negative correlation was seen between antibody titres in mothers and cord blood haemoglobin. No correlation was seen with antibody titres in mothers and grades of DAT. Correlation were significant at the 0.01 level.

\begin{tabular}{|c|c|c|c|}
\hline Variable (n- 44) & $\begin{array}{c}\text { Correlation } \\
\text { Coefficient }\end{array}$ & P value & Interpretation \\
\hline Grades of DAT & .000 & .998 & $\begin{array}{c}\text { No significant } \\
\text { correlation }\end{array}$ \\
\hline $\begin{array}{c}\text { Titres of antibody } \\
\text { in mothers }\end{array}$ & .052 & .739 & $\begin{array}{c}\text { No significant } \\
\text { correlation }\end{array}$ \\
\hline \multicolumn{2}{|c|}{ Table 4. Parity of Mothers of Infants with Rh-D HDFN } \\
\hline
\end{tabular}

In Rh-D HDFN parity was not significantly correlated with grades of DAT and titres of antibody in mothers. Correlation was significant at the 0.01 level.

\section{DISCUSSION}

44 neonates admitted in newborn nursery of Govt. Medical College, Thiruvananthapuram with Rh-D HDFN was studied.

In immune-mediated HDFN, lifespan of foetal or neonatal erythrocytes are shortened by placentally transferred maternal antibodies. ${ }^{1}$

Bjarte G. Solheim opined that immunisation had occurred when the foetal red cells were traversed through the placenta into maternal circulation or when the antigens were transferred by previous transfusions. ${ }^{7}$ Only maternal IgG antibodies could cross the placenta. ${ }^{7}$

Harvey Klein and David Anstee had opined that the Rh antigens were present only on red cells; hence, D immunisation evolved in D negative subjects either after injection of $\mathrm{D}$ positive red cells or following transplacental haemorrhage from a D positive foetus. ${ }^{8}$

Mollison et al observed that the D antigen was 20 times more immunogenic than $\mathrm{C}$, the next most potent $\mathrm{Rh}$ antigen. ${ }^{9}$ When D negative individuals were transfused with one or more units of D positive red cells, $80 \%$ - 90\% developed antiD within two months. ${ }^{10}$

Incidence of $\mathrm{D}$ immunisation depended on the dose of $\mathrm{D}$ positive RBCs, $15 \%$ after $1 \mathrm{~mL}, 33 \%$ after $40 \mathrm{~mL}$ and $65 \%$ to $70 \%$ after 250 mL. ${ }^{11}$ Secondary immune responses had occurred after exposure of $0.1 \mathrm{~mL}$ of Rh positive red cells. ${ }^{12}$

Hartmann had opined that approximately $1 \%$ of D negative women with no history of previous transfusion were found to be sensitised at the end of their first D positive pregnancy. ${ }^{13}$

But in this research no mother was without history of transfusion or pregnancy was sensitised. Bishop GJ and Krieger VI observed that when anti-D was developed during first pregnancy it was most commonly first detectable in the last few weeks of pregnancy or at the time of delivery. ${ }^{14}$

Krevans et al observed that foetal red cells could be detected in greater proportion of women towards the end of pregnancy than in the earlier stages. ${ }^{15}$

Frequency with which foetal red cells could be identified in the maternal circulation varied widely in various studies, i.e. $0.40 \%-5.8 \%$ at $28-30$ weeks and $1.84 \%-7.0 \%$ at $30-39$ weeks. ${ }^{16}$ Woodrow and Finn demonstrated a relationship between the number of foetal red cells in maternal circulation at the time of delivery and the chance of anti-D appearance thereafter. ${ }^{17}$

In an analysis by Boorman et al, the titre of anti-D was increased after delivery and a peak was reached by $1-3$ weeks. ${ }^{18}$ Six months after the birth of first D positive ABO compatible infant, incidence of anti-D in D negative women ranged from $4.3 \%$ to $9.0 \% .{ }^{19} \mathrm{R}_{2} \mathrm{r}$ infants were more effective in sensitising their mothers to D antigen. ${ }^{20}$

TPH was relatively common during normal delivery and a study by Woodrow showed that $65 \%$ of TPH occurred during delivery itself.21 In three investigations, estimates of the extent of TPH were similar; $1 \%$ of women had $3.0 \mathrm{~mL}$ or more and $0.3 \%$ had $10 \mathrm{~mL}$ or more of foetal red cells in their circulation at the time of delivery. ${ }^{22,23,24}$

Allowing free drain of placental blood immediately after cord clamping and infant separation had substantially reduced the incidence and magnitude of TPH. ${ }^{25}$ As per the research of Finn $\mathrm{R}$ et al caesarean section and manual removal of placenta were associated with five- to ten-fold increases in incidence and degree of TPH. ${ }^{26}$ 
Li et al found out that foetal distress during labour was significantly high when TPH was $5 \mathrm{~mL}$ or more.27 Two other routes through which foetal red cells could reach mother's peritoneal cavity and thence into maternal circulation were spillage of foetal blood into uterine cavity or fallopian tubes and hysterotomy or caesarean section. ${ }^{28}$ The protection observed in ABO incompatible situations was due to rapid clearance of A or B red cells, which prevented immunologic processing of $\mathrm{Rh}$ antigens. ${ }^{29}$ Murray et al noticed that group $\mathrm{A}$ incompatibility between infant and mother gave $90 \%$ and group B incompatibility gave $55 \%$ protection against D immunisation. ${ }^{30}$ Some D-negative infants born to D-positive mothers might develop anti-D within the first 6 months of life. 31,32

Zhu X, Meng had opined that placental transport was an active process dependent on interaction between maternal IgG and Fc receptors in synciotrophoblast. ${ }^{33}$ The transfer of IgG took place only from mother to foetus and not in the reverse direction. ${ }^{34}$ Even though only small amounts of IgG were transferred in first 12 weeks of gestation, DAT on foetal D positive red cells might be positive as early as $6-10$ weeks. ${ }^{35}$

Hay $\mathrm{FC}$ et al found out that $\operatorname{IgG}_{1}$ levels rose at an earlier stage of gestation than $\mathrm{IgG}_{3}$ levels. ${ }^{36}$ Although, foetal to maternal ratios of all four IgG subclasses were found to be similar in cord serum by Morell and co-workers, others found a relative deficiency of $\mathrm{IgG}_{2} .{ }^{37}$

The relative concentration of $\operatorname{IgG}_{1}$ in foetal serum compared with maternal serum was $1.77 .38 \mathrm{Fc} \gamma$ receptors in placental tissue were bound to $\operatorname{IgG}_{1}$ with a higher affinity than $\operatorname{IgG}_{2}{ }^{39}$

In infants with passively acquired anti-D, the antibody titre declined with a $\mathrm{T}_{1 / 2}$ of $2-3$ weeks and DAT remained positive for 3 months. ${ }^{34}$

Natvig et al reported that immunogenic Rh antibodies were mainly $\operatorname{IgG}_{1}$ followed by $\operatorname{IgG}_{3} .{ }^{40}$ Schur et al opined that $\mathrm{IgG}_{1}$ levels increased at an earlier gestational age than $\mathrm{IgG}_{3}$, whereas $\mathrm{IgG}_{3}$ coated red cells were rapidly cleared from circulation as compared to IgG 1 coated cells. ${ }^{41}$ As per Hughes Jones opinion, $\mathrm{Rh}$ antibodies did not activate complement completely. 42

Among $44 \mathrm{D}$ negative mothers in this research, high titres ranging from 128 - 1024 were observed in 45.5\%. In Rh-D HDFN titre of maternal antibody was positively correlated with risk related to peak bilirubin levels, severity of disease and intensity of treatment and negatively correlated with cord blood haemoglobin levels, while it was not correlated with grades of DAT.

Just as with our study another one conducted by Shaiji in same setting showed significant correlation between antibody titre in mothers of infants with Rh-D HDFN and umbilical cord bilirubin levels. ${ }^{43}$ ACOG has opined that critical titre of anti-D in maternal sera was usually 16 or 32 in the antihuman globulin phase. ${ }^{44}$

According to Alexander et al, a 4-fold increase in antibody titre was typically considered as a significant change which required foetal evaluation. ${ }^{45}$ Bowman opined that $\mathrm{Rh}$ antibody titration could predict the foetuses at risk, but not the severity of erythroblastosis. ${ }^{46}$ But Bowell et al demonstrated a clear relationship between increasing anti-D titre and the chance for a severely affected infant. 47
A low value of antibody concentration estimated using an auto-analyser had indicated that the infant would be mildly affected or unaffected and an increase in anti-D concentration indicated increasing severity of haemolytic disease. ${ }^{48}$

HDFN was less severe when only IgG 3 anti-D was present as compared to $\operatorname{IgG}_{1}$ alone or $\operatorname{IgG}_{1}$ and $\operatorname{IgG}_{3}$ together. ${ }^{49}$ Parinaud et al observed that when both $\operatorname{IgG}_{1}$ and $\operatorname{IgG}_{3}$ were present, $\operatorname{IgG}_{1}$ was usually preponderant and most severe disease was correlated with $\operatorname{IgG}_{1}$ levels. ${ }^{50}$

Distribution according to grades of DAT positivity in infants with Rh-D HDFN in present analysis had revealed a highest sharing in grade-2 reaction group. In our study, $22.7 \%$ of infants had grade- 3 or grade- 4 DAT.

Increasing grades of DAT were not at all correlated with severity of disease, intensity of treatment, risk related to peak bilirubin levels and cord blood haemoglobin values. Similarly, a research accomplished by Shaiji in same setting found no correlation between grades of DAT and intensity of treatment in Rh-D HDFN. 43

Likewise, Mollison and Cutbush opined that no correlation between DAT and severity of the disease. ${ }^{51}$ Harvey Klein and David Anstee observed that in Rh-D haemolytic disease, infants might have a strongly positive DAT without showing any clinical signs of disease. 52

Bjarte G. Solheim and Morten Grönn observed that some D positive infants with a positive DAT might show no signs of red cell destruction. ${ }^{3}$ Bowman opined that several factors such as Rh antibody binding constant, amount of $\mathrm{D}$ antigen on red cell membrane, ability of foetus to maintain a reasonable haemoglobin level, etc. had influenced the severity of erythroblastosis. ${ }^{46}$

In Rh-D haemolytic disease, infants might have a strongly positive DAT without showing any clinical signs of disease. ${ }^{52}$

The research was a descriptive one with a limited data. Hence, there were some limitations in assessing correlation between variables. For procuring more information longterm analytical studies have to be undertaken.

\section{CONCLUSION}

1. High titres of anti-D ranging from 128 - 1024 were observed in $45.5 \%$ of mothers of infants with Rh-D HDFN.

2. Titre of maternal anti-D was positively correlated with risk related to peak bilirubin levels, severity of disease and intensity of treatment and negatively correlated with cord blood haemoglobin levels.

3. While considering DAT positivity in infants with Rh-D HDFN, majority fell in grade 1 and 2 categories.

4. Increasing grades of DAT were not correlated with severity of disease, intensity of treatment, risk related to peak bilirubin levels and cord blood haemoglobin values.

\section{ACKNOWLEDGEMENT}

We acknowledge Dr. Anupa Lucas, Dr. Rajany Jose and Dr. Reshmi Ramachandran, Assistant Professors in Dept. of Community Medicine, Govt. Medical College, Thrissur, for their unwavering support and perpetual inspiration in this research. We offer our sincerest obligation to Dr. Lalitha Kailas, Professor and HOD in Dept. of Paediatrics, Gokulam Medical College, Trivandrum, and Dr. Shobha Kumar, Professor in Dept. of Paediatrics, Govt. Medical College, 
Trivandrum, for their scholarly guidance in the course of this work.

\section{REFERENCES}

[1] Kennedy MS. Perinatal issues in transfusion practice. AABB technical manual. 17th edn. AABB Press 2011:p. 631.

[2] Murray NA, Roberts IA. Hemolytic disease of the newborn. Arch Dis Child Fetal Neonatal Ed 2007;92(2):F83-8.

[3] Simon TL, Snyder EL, Solheim BG, et al. Hemolytic disease of the fetus and newborn. In: Solheim BG, Grönn M, eds Rossi's principles of transfusion medicine. $4^{\text {th }}$ edn. Blackwell Publishing Ltd 2009:p. 423.

[4] Hadley AG, Wilkes A, Goodrick J, et al. The ability of the chemiluminescence test to predict clinical outcome and the necessity for amniocenteses in pregnancies at risk of haemolytic disease of the newborn. BJOG 1998;105(2):231-234.

[5] Greer GP, Foerster J, Rodgers GM, et al. Wintrobe's clinical hematology. $12^{\text {th }}$ edn. Philadelphia: Lippincott Williams \& Wilkins 2009:p. 982.

[6] Greer GP, Foerster J, Rodgers GM, et al. Wintrobe's clinical hematology. $12^{\text {th }}$ edn. Lippincott Williams \& Wilkins 2009:p. 992.

[7] Solheim BG, Grönn M. Hemolytic disease of the fetus and newborn. Rossi's principles of transfusion medicine. $4^{\text {th }}$ edn. Blackwell Publishing Ltd 2009:419420.

[8] Klein H, Anstee D. Mollison's blood transfusion in clinical medicine. $11^{\text {th }}$ edn. Blackwell Publishing Ltd 2005:p. 498.

[9] Mollison PL, Engelfriet CP, Contreras M. Blood transfusion in clinical medicine. $9^{\text {th }}$ edn. Boston: Blackwell Scientific Publications 1993.

[10] Woodrow JC, Clarke CA, MCConnell RB, et al. Prevention of Rh-haemolytic disease: results of the Liverpool low risk clinical trial. $\mathrm{Br}$ Med J 1971;2(5762):610-2.

[11] Pollack W, Ascari WO, Kochesky RJ, et al. Studies on Rh prophylaxis. I. Relationship between doses of anti-Rh and size of antigenic stimulus. Transfusion 1971;11(6):333-9.

[12] Bowman JM. The prevention of $\mathrm{Rh}$ immunization. Transfus Med Rev 1988;2(3):129-50.

[13] Hartmann 0, Brendemoen OJ. Incidence of $\mathrm{Rh}$ antibody formation in first pregnancies outcome of pregnancies in 23 cases not previously sensitized to Rh antigens. Acta Paediatr (Uppsala) 1953;42(1):20-3.

[14] Bishop GJ, Krieger VI. The timing of rhesus immunization and the prevention of antibody response using anti-Rh immune globulin. Aust NZ J Obstet Gynaecol 1969;9(4):228-31.

[15] Krevans JR, Woodrow JC, Nosenzo C, et al. Patterns of Rh-immunization. Stockholm: Commun 10th Congr Int Soc Haematol 1964.

[16] Huchet J, Defossez Y, Brossard Y. Detection of transplacental hemorrhage during the last trimester of pregnancy (Letter). Transfusion 1988;28(5):506.

[17] Woodrow JC, Finn R. Transplacental haemorrhage. Br J Haematol 1966;12(3):297-309.
[18] Boorman KE, Dodd BE, Mollison PL. Iso-immunisation to the blood-group factors A, B and Rh. J Pathol Bact 1945;57(2):157-69.

[19] Klein H, Anstee D. Mollison's blood transfusion in clinical medicine. $11^{\text {th }}$ edn. Blackwell Publishing Ltd 2005:p. 506.

[20] Murray S. The effect of Rh genotypes on severity in haemolytic disease of the newborn. Br J Haematol 1957;3(2):143-52.

[21] Woodrow JC, Clarke CA, Donohoe WTA, et al. Prevention of Rh-haemolytic disease: a third report. BMJ 1965;1(5430):279-83.

[22] Bartsch FK. Fetale Erythrozyten im mütterlichen Blutund Immunprophylaxe der Rh-Immunisierung. Klinischeund experimentelle Studie. Acta Obstet Gynecol Scand 1972;20(Suppl):1-128.

[23] Zipursky A. The universal prevention of $\mathrm{Rh}$ immunization. Clin Obstet Gynecol 1971;14(3):86984.

[24] Woodrow JC, Donohoe WT. Rh-immunization by pregnancy: results of a survey and their relevance to prophylactic therapy. BMJ 1968;4(5624):139-44.

[25] Terry MF. A management of the third stage to reduce feto-maternal transfusion. J Obstet Gynaecol $\mathrm{Br}$ Commonw 1970;77(2):129-32.

[26] Finn R, Harper DT, Stallings SA, et al. Transplacental hemorrhage. Transfusion 1963;3(2):114-24.

[27] Li TC, Bromham DR, Balmer BM. Fetomaternal macrotransfusion in the Yorkshire region. 1. Prevalence and obstetric factors. Br J Obstet Gynaecol 1988;95(11):1144-51.

[28] Hindemann P. Experimentelle und klinische Untersuchungenüber eine transabdominale Späteinschwemmungfetaler Erythrozyten in den mütterlichen Kreislauf. Gerburtsh Frauenheilk 1966;26:1359.

[29] Klein H, Anstee D. Mollison's blood transfusion in clinical medicine. $11^{\text {th }}$ edn. Blackwell Publishing Ltd 2005:p. 502.

[30] Murray S, Knox EG, Walker W. Rhesus haemolytic disease of the newborn and the ABO groups. Vox Sang 1965;10:6-31.

[31] Owen RD, Wood HR, Foord AG, et al. Evidence for actively acquired tolerance to $\mathrm{Rh}$ antigens. Proc Natl Acad Sci USA 1954;40(6):420-4.

[32] Ward HK, Walsh RJ, Kooptzoff O. Rh antigens and immunological tolerance. Nature (Lond) 1957;179(4574):1352-3.

[33] Zhu X, Meng G, Dickinson BL, et al. MHC class I-related neonatal Fc receptor for IgG is functionally expressed in monocytes, intestinal macrophages and dendritic cells. J Immunol 2001;166(5):3266-76.

[34] Klein H, Anstee D. Mollison's blood transfusion in clinical medicine. $11^{\text {th }}$ edn. Blackwell Publishing Ltd 2005:p. 497.

[35] Chown B. On a search for rhesus antibodies in very young foetuses. Arch Dis Child 1955;30(151):232-3.

[36] Hay FC, Hull MG, Torrigiani G. The transfer of human IgG subclasses from mother to foetus. Clin Exp Immunol 1971;9(3):355-8. 
[37] Morell A, Skvaril F, van Loghem E, et al. Human IgG subclasses in maternal and fetal serum. Vox Sang 1971;21(6):481-92.

[38] Einhorn MS, Granoff DM, Nahm MH, et al. Concentration of antibodies in paired maternal and infant sera: relationship to IgG subclass. J Pediatr 1987;111(5):783-8.

[39] McNabb T, Koh TY, Dorrington KJ, et al. Structure and function of immunoglobulin domains. V. Binding of immunoglobulin $G$ and fragments to placental membrane preparations. J Immunol 1976;117(3):8828.

[40] Natvig JB, Kunkel HG. Genetic markers of human immunoglobulins: the $\mathrm{Gm}$ and Inv systems. Ser Haematol 1968;1:66.

[41] Schur PH, Alpert E, Alper C. Gamma G subgroups in human fetal, cord, and maternal sera. Clin Immunol Immunopathol 1973;2(1):62-6.

[42] Hughes-Jones NC, Ghosh S. Anti-D-coated Rh-positive red cells will bind the first component of the complement pathway, C1q. FEBS Lett 1981;128(2):318-20.

[43] Shaiji PS. Clinical profile and outcome of Rh-D alloimmunized pregnancies in a tertiary care centre. MD Thesis 2011.

[44] Management of isoimmunization in pregnancy. ACOG Educational Bulletin Number 227. Washington, DC: American College of Obstetricians and Gynecologists 1996.
[45] Wiener AS, Nappi R, Eve B. Studies in Rh sensitization: III. Effect of Rh-positive pregnancies on Rh. Antibody Titer. Blood 1951;6:789-98.

[46] Bowman JM. Management of isoimmunisation. Obstet Gynaecology 1978;52(1):1-16.

[47] Bowell PJ, Wainscot JS, Peto TEA, et al. Maternal anti-D concentrations and outcome in rhesus haemolytic disease of the newborn. BMJ 1982;285(6338):327-9.

[48] Hadley AG, Garner SF, Taverner JM. Auto analyzer quantification, monocyte-mediated cytotoxicity and chemiluminescence assays for predicting the severity of haemolytic disease of the newborn. Transfus Med 1993;3(3):195-200.

[49] Pollock JM, Bowman JM. Anti-Rh(D) IgG subclasses and severity of Rh hemolytic disease of the newborn. Vox Sang 1990;59(3):176-9.

[50] Parinaud J, Blanc M, Grandjean H, et al. IgG subclasses and $\mathrm{Gm}$ allotypes of anti-D antibodies during pregnancy: correlation with the gravity of the fetal disease. Am J Obstet Gynecol 1985;151(8):1111-5.

[51] Mollison PL, Cutbush M. A method of measuring the severity of a series of cases of hemolytic disease of the newborn. Blood 1951;6(9):777-88.

[52] Klein H, Anstee D. Mollison's blood transfusion in clinical medicine. $11^{\text {th }}$ edn. Blackwell Publishing Ltd 2005:p. 531. 